Review

\title{
Application of polyvinyl alcohol (PVA) in cement-based composite materials: A review of its engineering properties and microstructure behavior
}

\author{
C.C. Thong, D.C.L. Teo *, C.K. Ng \\ Faculty of Engineering, Universiti Malaysia Sarawak, 94300 Kota Samarahan, Sarawak, Malaysia
}

\section{H I G H L I G H T S}

- Physical properties of PVA.

- Application of PVA in cement-based composite materials.

- Effects of PVA on the engineering properties of cement-based composite materials.

- Effects of PVA on the microstructure behavior of cement-based composite materials.

\section{A R T I C L E I N F O}

\section{Article history:}

Received 3 July 2015

Received in revised form 17 December 2015

Accepted 24 December 2015

Available online 11 January 2016

\section{Keywords:}

Polyvinyl alcohol

Engineering properties

Fracture surface

Interfacial transition zone

Composition changes

\begin{abstract}
A B S T R A C T
Polyvinyl alcohol (PVA) was created about 90 years ago as the first synthetic colloid and it has been used for various applications since then. One of the significant applications of PVA is in the building industry. It was found that PVA can be used as a modifier, aggregate surface pre-treatment agent and fiber reinforcement in cement-based composite materials. This paper provides a review on the physical properties of PVA and discusses on the effects of PVA towards the engineering properties of cement-based composite materials. The effects of PVA on the changes in the fracture surface, structure of the interfacial transition zone (ITZ) and composition in ITZ of cement-based composite materials are also presented. In addition, the needs in research for future development of PVA in the building industry are also addressed.
\end{abstract}

(c) 2015 Elsevier Ltd. All rights reserved.

\section{Contents}

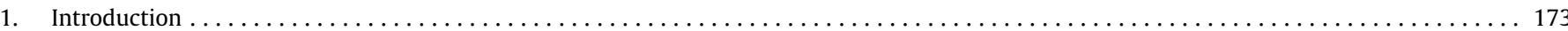

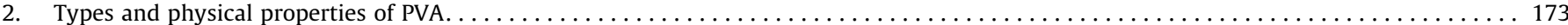

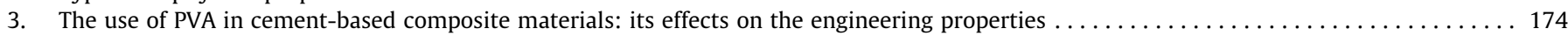

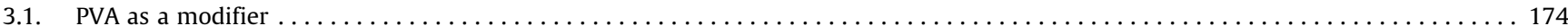

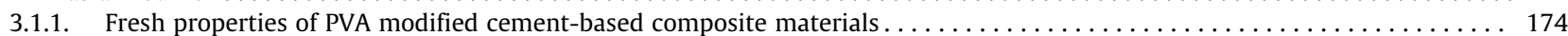

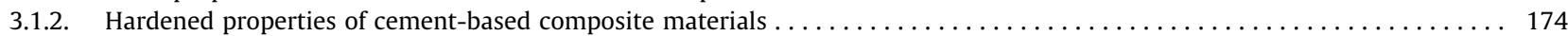

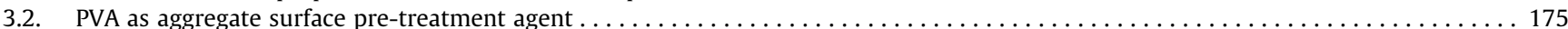

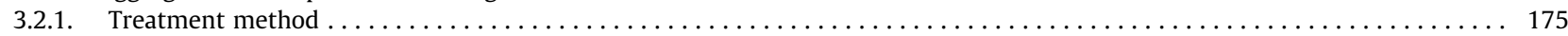

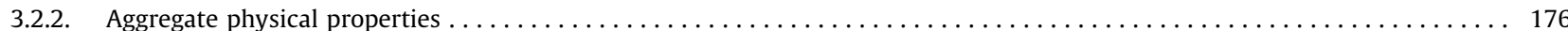

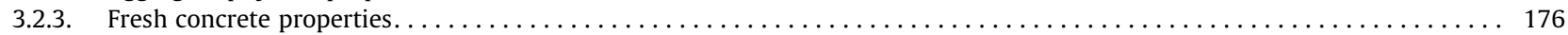

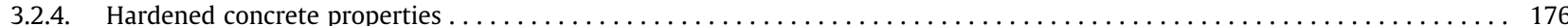

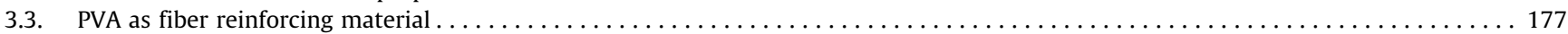

3.3.1. Engineering properties of cement-based composite materials containing PVA fiber. . . . . . . . . . . . . . . . .

\footnotetext{
* Corresponding author.

E-mail addresses: thong_cc38@hotmail.com (C.C. Thong), tdelsye@unimas.my (D.C.L. Teo), ckng@unimas.my (C.K. Ng).
} 